\title{
Interstitial cells from the testis of the trout (Oncorhynchus mykiss) in vivo and in primary culture
}

\author{
Maurice Loir \\ Physiologie des Poissons, INRA, Campus de Beaulieu, Rennes, France
}

Accepted February 26, 1990

Summary. In the testis of the trout, while no changes are apparent in myoid cells at any stage of maturation, Leydig cells display striking structural alterations when observed at different periods of the reproductive cycle. Spermiating testes contain fully differentiated Leydig cells. In regressed testes and those involved in spermatogenesis, poorly differentiated Leydig cells are mixed with cells ranging structurally from normal Leydig cells to fibroblast-like elements. After 3-4 days in culture the myoid cells/fibroblasts progressively acquire the ability to proliferate and then show a positive reaction for $3 \beta$ hydroxysteroid dehydrogenase. During the same period they undergo structural changes reflecting the emergence of a steroidogenic activity. These changes occur concomitantly with an increase in progestagen secretion. These data suggest that, in vivo, Leydig cells degenerate at the end of a cycle, being then replaced by fibroblastic precursor cells capable of division and differentiation into steroidogenic cells.

Key words: Testis - Interstitial cells - Cell culture - Steroids - Oncorhynchus mykiss (Teleostei)

In the testis of teleost fish, although Sertoli cells and spermatozoa may produce steroids (Nagahama 1986; Sakai et al. 1989; Loir 1990 b), Leydig cells are the principal source of testicular steroids (for review, see Nagahama 1986; Loir 1990b). These cells are usually distributed singly or in small groups in the interstices between the seminiferous lobules. Also present in the interstitium (Fig. 1) are blood vessels, collagen fibers and fibroblastlike cells, which have been termed boundary cells or "myoid cells" (Grier 1981), although it is uncertain whether in fish they have a contractile function as has been shown in mammals. The testis of teleosts lacks a lymphatic system.

Send offprint requests to: M. Loir, Physiologie des Poissons, INRA, Campus de Beaulieu, F-35042 Rennes Cedex, France
The ultrastructure of interstitial cells and especially Leydig cells has been described for several fish species. Although it has been suggested in two fish species that Leydig cells may arise from interstitial fibroblasts (Nicholls and Graham 1972; Yeung et al. 1985), their origin has not yet been ascertained in other teleosts. Only a few studies have dealt with morphological changes in Leydig cells throughout the reproductive cycle of fish (Yeung et al. 1985; Loir et al. 1989). At present, the fate of Leydig cells at the end of a cycle remains uncertain, i.e., it is open to discussion whether they die and are replaced by new steroidogenic cells.

Abundant literature is available documenting various aspects of the interdependence of the seminiferous tubules and the interstitial tissue in mammalian testis. However, in laboratory mammals all spermatogenetic stages are present simultaneously in the testis, and the question whether Leydig cells in a particular functional state are associated with certain spermatogenic stages is rather difficult to answer. Non-mammalian vertebrates, such as the amphibian Necturus maculosus (Pudney et al. 1983), the protogynous fish Monopterus albus (Yeung et al. 1985), and seasonally breeding fish such as Myleus ternetzi (Loir et al. 1989) have proven to be useful for investigating changes occurring in the two major testicular compartments in relation to each other. Although salmonids, which also breed seasonally, constitute a particularly interesting model for such studies, no investigation in this field has been previously carried out.

Recently, we introduced a method to prepare cell populations enriched in interstitial cells from testes of the trout, Oncorhynchus mykiss, at all maturational stages and to maintain a differentiated activity in culture for 1-2 weeks (Loir 1988; Loir 1990 b). In the present study, data concerning morphological and ultrastructural changes, as well as additional observations of changes in steroidogenic activity, are reported in interstitial cells collected at certain maturational stages and cultured invitro. As information about the various cell types present at these stages in the interstitium was a prerequisite 
to such a study, a brief description of the cells observed in situ is also reported. Furthermore, the comparison of in vitro and in vivo data has suggested working hypotheses for further investigations.

\section{Materials and methods}

\begin{abstract}
Animals
Twenty-one 1- to 3-year-old male autumn-spawning and springspawning rainbow trout (Oncorhynchus mykiss) were used. They were kept at $12-14^{\circ} \mathrm{C}$ under natural photoperiod and killed by a blow on the head after having been anesthetized with $0.3 \%$ phenoxyethanol. Testes were removed (under sterile conditions for cell culture) and the stage of maturation was determined according to Billard and Escaffre (1975). Stage III corresponds to the beginning of spermatogenesis, stages IV and V to spermatogenesis, stages VII and VIII a to spermiating testes, stage VIII b to testes approaching the end of spermiation, and stage IX to regressed testes.
\end{abstract}

\section{Preparation of cell populations and culture}

The techniques used to dissociate trout testes and to prepare testicular cell populations have been described previously (Loir 1988). Briefly, after enzymatic dissociation of the testis, most of the spermatozoa were removed. The resulting cell suspension ("round testicular cells") was fractionated using a two-step procedure (flow sedimentation at unit gravity, then Percoll density gradient centrifugation), and two populations enriched in interstitial cells were collected. One of the populations contained single interstitial cells (approximately $65-80 \%$ of the somatic cells); the remaining cells consisted of macrophages, different blood cells, variable numbers of round germ cells, depending on the stage of maturation, and a few Sertoli cells. The other population contained mostly clustered interstitial cells. In terms of somatic cell composition this population was usually at least $95 \%$ pure (except for stage-III testes: around $50 \%$ ). Sertoli cells were the other major somatic cell present $(\leq 4 \%)$. Spermatozoa also occurred in variable numbers depending on the testis, but they degenerated in culture and were progressively removed at every change of medium.

Cells were cultured in plastic multiwell plates coated with fibronectin. The culture medium (modified L-15 Leibovitz medium; Loir 1988) was supplemented with $2 \%$ Ultroser (steroid-free serum substitute, IBF, Villeneuve-la-Garenne, France). Highly purified salmon gonadotropin (s-GtH, Breton et al. 1978) was either added in the range of $0-200 \mathrm{ng} / \mathrm{ml}$, or omitted. Occasionally, $100 \mu \mathrm{M}$ $22-\mathrm{OH}-\mathrm{cholesterol}$ was added. Depending on the stage of maturation and the cell population, 2 to $35 \times 10^{6}$ round cells $/ \mathrm{ml}$ were seeded. Cells in suspension and nuclei prepared with $0.4 \%$ hexadecyltrimethylammonium bromide (HTAB) were counted using a hemocytometer on a phase-contrast microscope. Cell viability was determined by the $0.2 \%$ erythrosine dye-exclusion test.

\section{Identification of the steroidogenic cells}

Histochemical staining for $3 \beta$-hydroxysteroid dehydrogenase ( $3 \beta$ HSD) was performed by modifying the method of Levy et al. (1959) as described by Loir (1988). The percentage of violet-stained cells was estimated and used to determined, after total cell counts, the number of Leydig cells per $\mathrm{ml}$.

\section{Incorporation of ${ }^{3} \mathrm{H}$-thymidine}

At various times after seeding and $24 \mathrm{~h}$ before the cells were harvested, $8 \mu \mathrm{Ci}$ of ${ }^{3} \mathrm{H}$-thymidine (specific activity: $0.92 \mathrm{TBQ} / \mathrm{mM}$ ) was added per $\mathrm{ml}$ culture medium. When incubation was stopped, culture medium was collected and as many germ cells as possible were removed (Loir 1989). Spread cells were washed twice for $1.5 \mathrm{~h}$ with fresh medium, and the nuclei were prepared with $1 \mathrm{ml}$ HTAB solution and counted. They were collected by filtration on $\mathrm{GF} / \mathrm{C}$ Whatman filters, and then washed with $10 \mathrm{ml} 5 \%$ perchloric acid and $10 \mathrm{ml}$ ethanol. Filters were dried and counted in $4 \mathrm{ml} \mathrm{OCS}$ scintillator in a Tricarb counter.

\section{Electron microscopy}

Cells were fixed for $30 \mathrm{~min}$ in $2.5 \%$ glutaraldehyde in $0.1 \mathrm{M}$ cacodylate buffer, $\mathrm{pH} 7.4$, containing $5 \mathrm{mM} \mathrm{CaCl}_{2}$, then postfixed in $1 \%$ osmium tetroxide in the same buffer containing $1.5 \%$ potassium ferricyanide and $1 \%$ sucrose. The attached cells were freed by gentle scraping, then embedded in $2 \%$ agar before being dehydrated in acetone and embedded in a mixture of Epon-Araldite. Six testes at specific stages of maturation were fixed by vascular perfusion via the testicular vein with $5 \%$ glutaraldheyde in the same buffer as above. Tissue blocks were postfixed, washed and embedded in the same way as described for the cells. Sections were double-stained and observed with a $100 \mathrm{CX}$ Jeol electron microscope.

\section{Steroid radioimmunoassays}

Steroids were assayed in culture media after extraction with ethylacetate:cyclohexane $(50: 50)$ as described in detail elsewhere (Loir 1990 a). Briefly, the radioimmunoassays for $17 \alpha, 20 \beta$ dihydroprogesterone $(17 \alpha 20 \beta-\mathrm{OH}-\mathrm{P})$ and testosterone $(\mathrm{T})$ were performed as described by Fostier and Jalabert (1986). 11-ketotestosterone $(11 \mathrm{KT})$ was assayed according to Fostier et al. (1982), and $17 \alpha-$ hydroxyprogesterone (17 $\alpha-\mathrm{OH}-\mathrm{P})$ and androstenedione were assayed similarly. For these 5 radioimmunoassays the main crossreactivities with progestagens and androgens were below $5 \%$.

\section{Results}

\section{Interstitial cells in situ}

In trout, the basal lamina is rather thin and the interlobular spaces are generally narrow. At all stages of maturation, the seminiferous lobules are very loosely surrounded by cells resembling myofibroblasts (Gabbiani and Montandon 1977), and termed "myoid cells" (Fig. 1). These cells are separated from the basal lamina and from the other interstitial cells by abundant collagen fibers. The myoid cells have an elongated heterochromatin-rich nucleus and very long, electron-dense cytoplasmic processes filled with tonofilaments and fringed with pinocytotic vesicles. The diameter of mitochondria is usually small (under $0.25 \mu \mathrm{m}$ ), and cisternae of the rough endoplasmic reticulum (RER) are present in some circumscribed areas.

Although no thorough study has been carried out, it appears that the relative amount and the ultrastructure of the other interstitial cells (excluding the endothelial cells) differ according to the stage of maturation of the testis. At the beginning of spermiation (stage VIIIa), most of the interstitial cells display characteristic features of fully differentiated Leydig cells (Fig. 2a). The greater part of the cytoplasm is filled with smooth endo- 


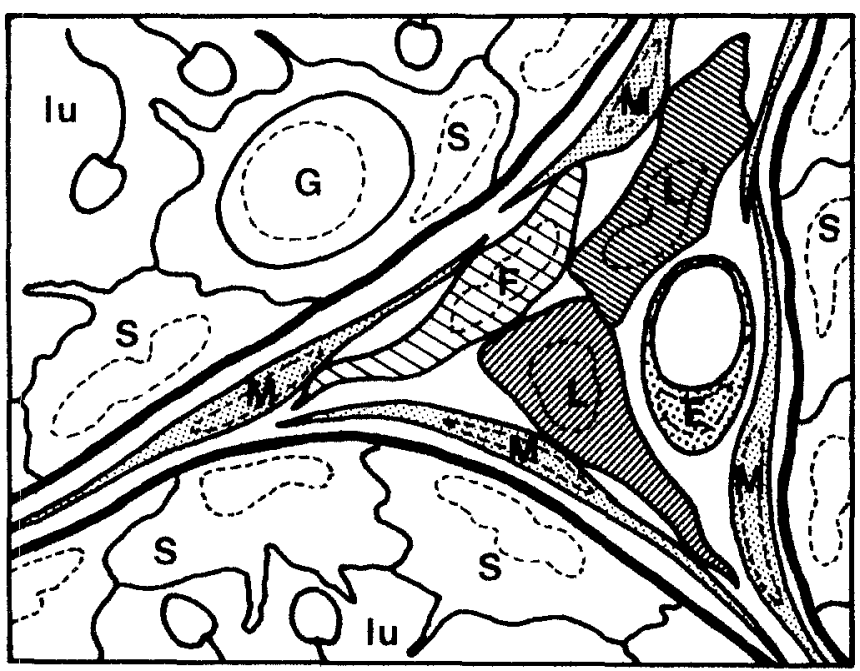

Fig. 1. Schematic representation of the cellular organization in the testis of the trout at stages VII to IX. Interstitium adjacent to 3 seminiferous lobules. $L$ Leydig cells; $F$ fibroblast-like cell; $M$ myoid boundary cells; $E$ endothelial cell; $S$ Sertoli cells; $G$ Aspermatogonium; $l u$ lumen of the lobules containing spermatozoa

plasmic reticulum (SER) composed mainly of entwined tubules and of some scarce, closely spaced arrays of parallel tubules. Numerous mitochondria displaying an electron-dense matrix and tubulovesicular cristae are scattered in the cytoplasm. Their mean diameter is between 0.3 and $0.6 \mu \mathrm{m}$. Some free ribosomes, cisternae of RER, profiles of the Golgi apparatus and membrane-limited osmiophilic granules are also present. The nuclei of these cells are variable in shape due to deep invaginations and contain scattered clumps of heterochromatin and a nucleolus.

At the end of the spermiation period (stage VIIIbIX), several Leydig cells display ultrastructural features similar to those described above. However, the cytoplasm is generally less organized (Fig. 2b) containing fewer SER tubules. In the other Leydig cells (Fig. 2c), the cytoplasm shows conspicuous modifications: there is a partial loss of SER, occurrence of large vacuoles, multivesicular bodies, glycogen granules, and an increase in the number and size of the dense bodies. Furthermore, the mitochondria show an electron-translucent matrix and tubular cristae. In some mitochondria the cristae have partly disappeared.

At the beginning of spermatogenesis (stage III) and during spermatogenesis (stage IV), no typical, fully differentiated Leydig cells are apparent. Some of the cells located in the central regions of the interstitial spaces (Fig. 2d) possess most of the characteristic ultrastructural features of Leydig cells, but the SER is reduced and often composed of parallel tubules. In addition, there are usually more free ribosomes and dense bodies than at the time of spermiation. The ultrastructure of most of the other centrally located cells is intermediate between that of fibroblasts and Leydig cells, exhibiting typical features of one or the other cell type (Fig. 2d). Variations concern the amount of SER, RER, dense bodies, tonofilaments, pinocytotic vesicles, the diameter of mitochondria and the shape of the nucleus. Such cells are scarcely observed at stage VIII b-IX.

Regardless of the stage of maturation, intercellular contacts resembling gap junctions are frequently observed between Leydig cells, between the long processes formed by the myoid cells, and between the two cell types.

Macrophages are always present in the interstitium. However, in males that have already spawned once, they are especially numerous at the beginning of the next reproductive cycle (stage III). They very likely participate in the resorption of the unreleased spermatozoa. Indeed, we observed macrophages passing through the basal lamina and, after dissociation of the testis, macrophages containing damaged sperm nuclei in their cytoplasm (not shown).

\section{Ultrastructure of interstitial cells after cell separation}

The ultrastructure of these cells was observed at the time of seeding (i.e., 1 day after castration) for cells prepared from stage-IV to V testes (2) and from stage-VIII a testes (3). When the enzymatic treatment lasted only 6-7 h, no conspicuous difference was observed compared to the in-situ ultrastructure. However, when it lasted overnight, the density of the mitochondrial matrix was decreased and many of the cristae had become tubular (Fig. 9a in Loir 1988). There was no apparent ultrastructural difference between the single interstitial cells and those arranged in clusters.

Leydig cells prepared from stage-VIIIa testes (Fig. 3a) displayed some variability in the cytoplasmic concentration of free ribosomes, in the relative proportion of entwined and parallel SER tubules, and in the density of the material present in these tubules.

At the two stages of maturation studied, the ultrastructure of the myoid cells/fibroblasts (Fig. $3 \mathrm{~b}$ ) was identical to that observed in situ, except that pinocytotic vesicles were more numerous at the periphery of these cells. As observed in situ, mitochondria were smaller than those characteristic of Leydig cells (Fig. $3 \mathrm{c}$ ). In addition, the cytoplasm showed a variable electron density, depending on the individual cell (Fig. $3 b, c$ ).

The interstitial cell clusters consisted of myoid cells/ fibroblasts, Leydig cells and some endothelial cells. No macrophages or other cell types were observed.

\section{Morphology of interstitial cells in culture}

In the presence of $2 \%$ Ultroser, all the interstitial cells adhered to the fibronectin-coated plastic after 15-20 h. The cells spread slowly, especially when seeded in clusters; then they displayed a fibroblastoid morphology. Although cellular appearance was similar in the two populations at the time of seeding, it differed after several days in culture (Fig. 4a, b; Fig. 3 b in Loir 1988). Indeed, after $2.5-5$ days, those seeded as single cells became thin and elongated, while those seeded as clusters were broader and slightly larger. 

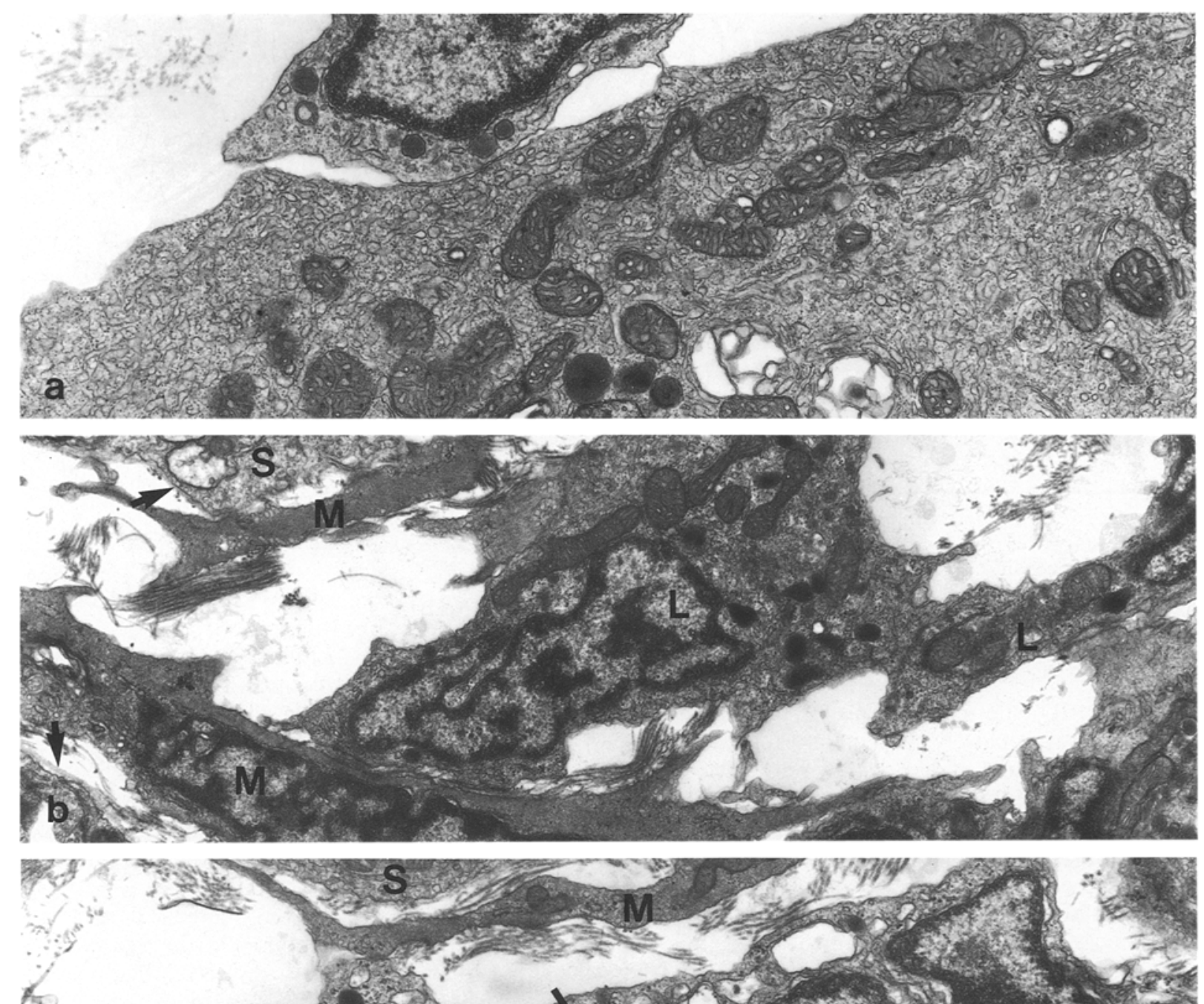

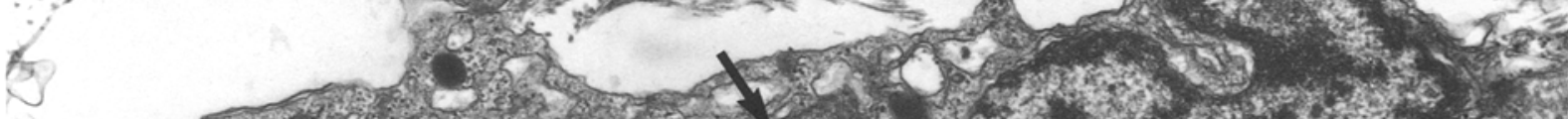

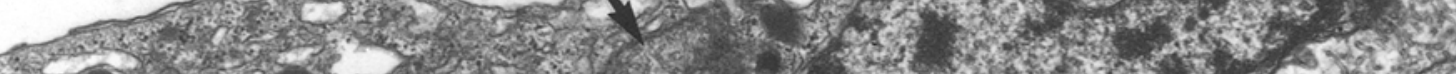

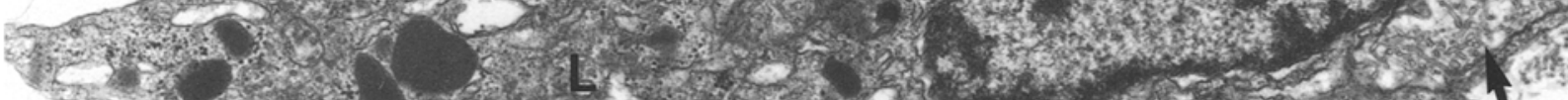

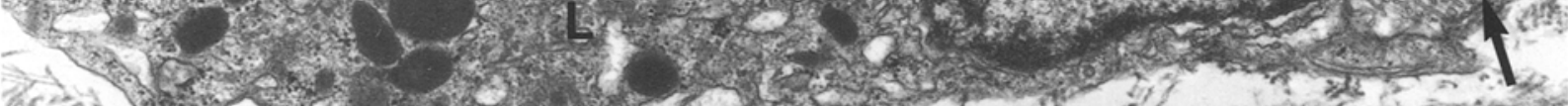

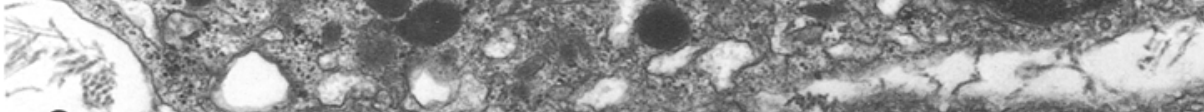

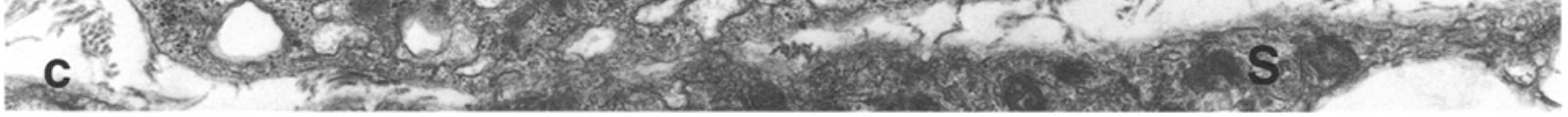

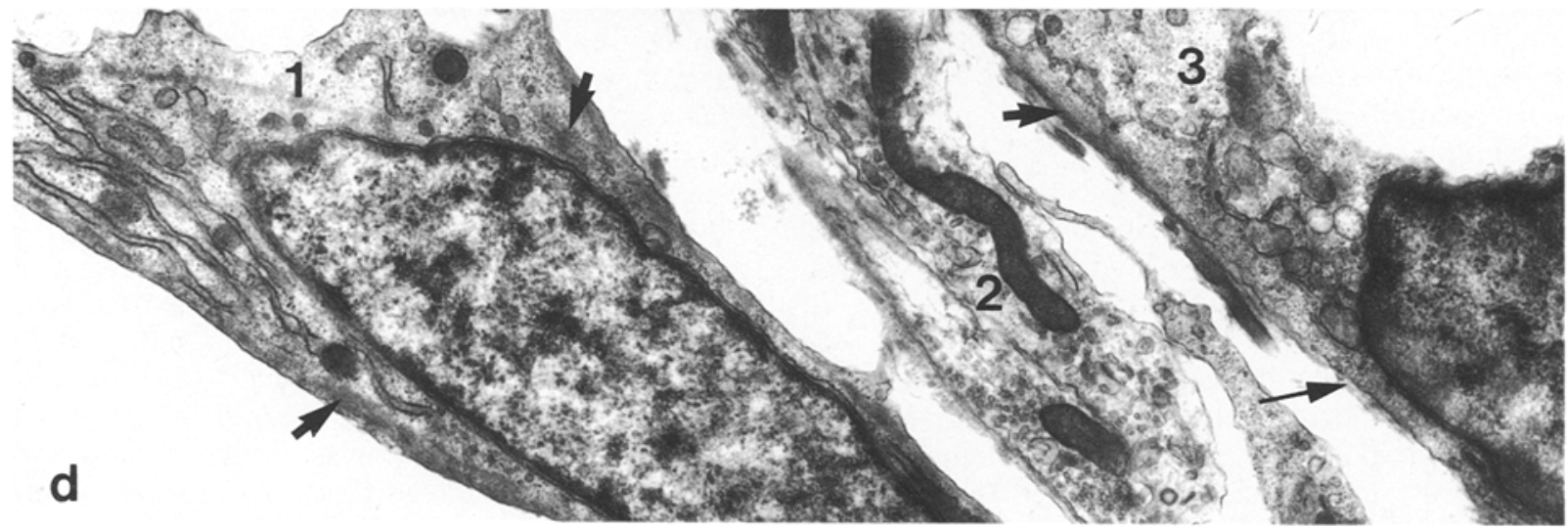



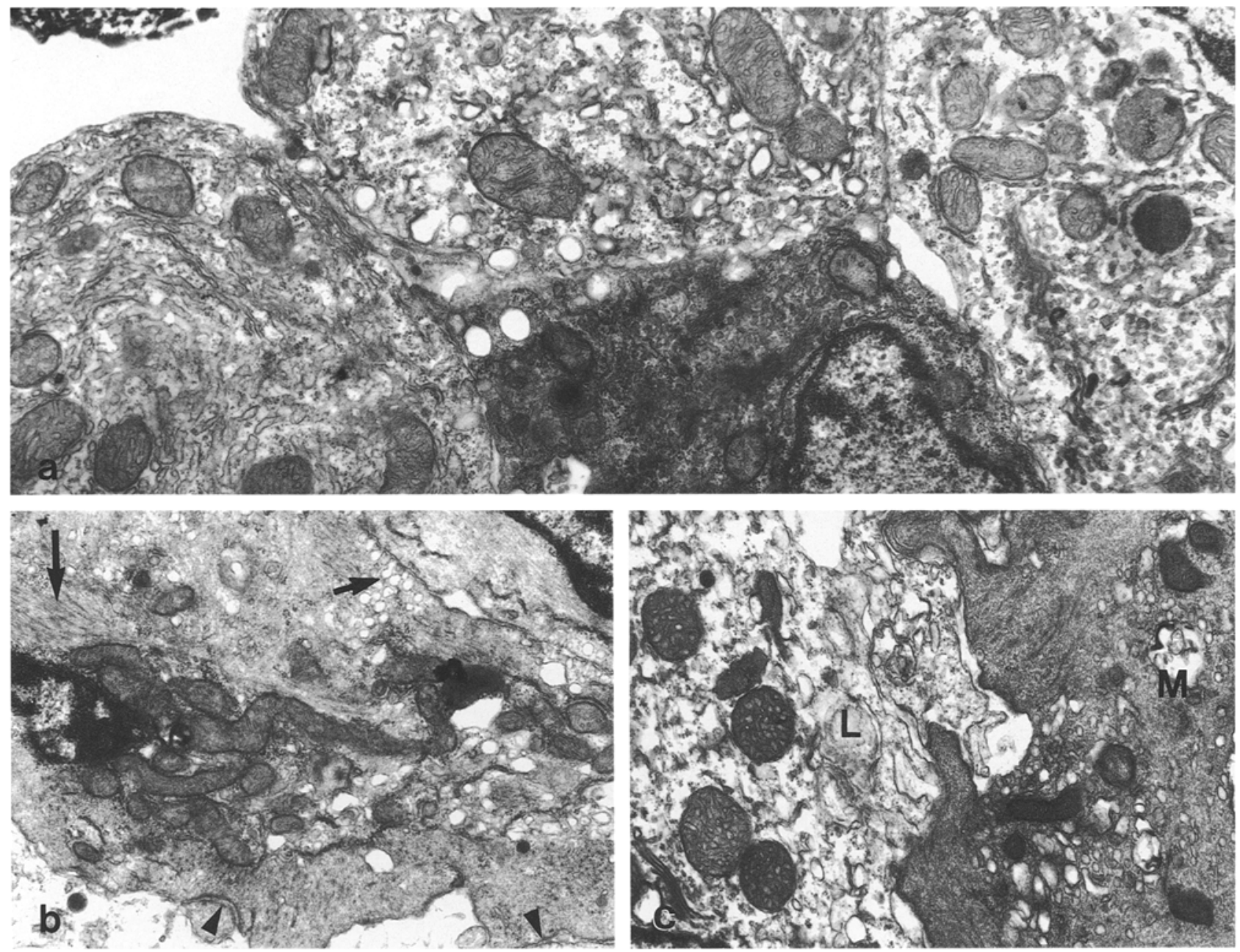

Fig. 3a-c. Interstitial cells at the time of seeding; cell-cluster population prepared from a stage-VIII a testis. a Four Leydig cells displaying a somewhat differing cytoplasmic organization. $\times 17800$. b Two myoid cells/fibroblasts. Small arrows pinocytotic vesicles; large arrow filaments; arrowheads intercellular junctions. $\times 18000$. c Myoid cell/fibroblast $(M)$ and Leydig cell $(L) . \times 17400$

\section{Proliferation of interstitial cells in culture}

This was investigated in cell populations prepared from one stage-III testis, one stage-V testis and four stage-VII to VIII a testes and cultured on plastic. In cultures of

Fig. 2a-d. Interstitial cells in situ. a Two fully differentiated Leydig cells in a stage-VIIIa testis. $\times 15700$. b Leydig cells $(L)$ and myoid cells $(M)$ in a stage-VIII b to IX testis. $S$ Sertoli cell; small arrows basal lamina. $\times 12300$. c Degenerating Leydig cell $(L)$ and myoid cell $(M)$ in a stage-VIII b to IX testis. Arrows mitochondria with a clear matrix and tubular cristae; $S$ Sertoli cells. $\times 16100$. d Three centrally located interstitial cells in a stage-III testis. Cell 1 possesses few tonofilaments (small arrows) and an abundant rough endoplasmic reticulum. In cell 2 mitochondria display a small diameter, an electron-dense matrix and tubulovesicular cristae. Cell 3 possesses few filaments (small arrow), some pinocytotic vesicles (long arrow), and mitochondria with a clear matrix. $\times 15000$ single interstitial cells, some mitotic cells were observed as early as 7 days. In cultures of interstitial-cell clusters, individual cells outside of the clustered elements were not seen to divide until 12 days after seeding.

The numbers of cells present on defined areas of plastic suggested that the single cells show moderate proliferation between 4 and 12 days, while those seeded in clusters proliferated more rapidly, at least until 12 15 days after seeding. At stage VII-VIIIa, nuclear counts (after cell lysis by use of HTAB treatment) indicated that the number of single cells increased by 1.2 -fold between day 4 and 10 , while that of the cells seeded in clusters increased by 1.8 to 2-fold. Microphotographs were taken daily of some clusters (prepared from one stage-VIII a testis) to follow their spreading on plastic during culture. It appeared (Fig. $4 \mathrm{c}$, d) that the number of cells separating from the clusters increased, starting from day 5; however during the same period the volume of the cluster proper did not seem to decrease.

Incorporation of ${ }^{3} \mathrm{H}$-thymidine by interstitial cells prepared from a stage-VIII a testis (Fig. 5) showed that: (1) interstitial cells synthesized DNA as early as day 5 in culture; (2) DNA synthesis by $10^{6}$ cells was higher for cells seeded in clusters than for single cells; (3) DNA synthesis by cells seeded in clusters increased rapidly at least until day 11, while DNA synthesis by single cells 

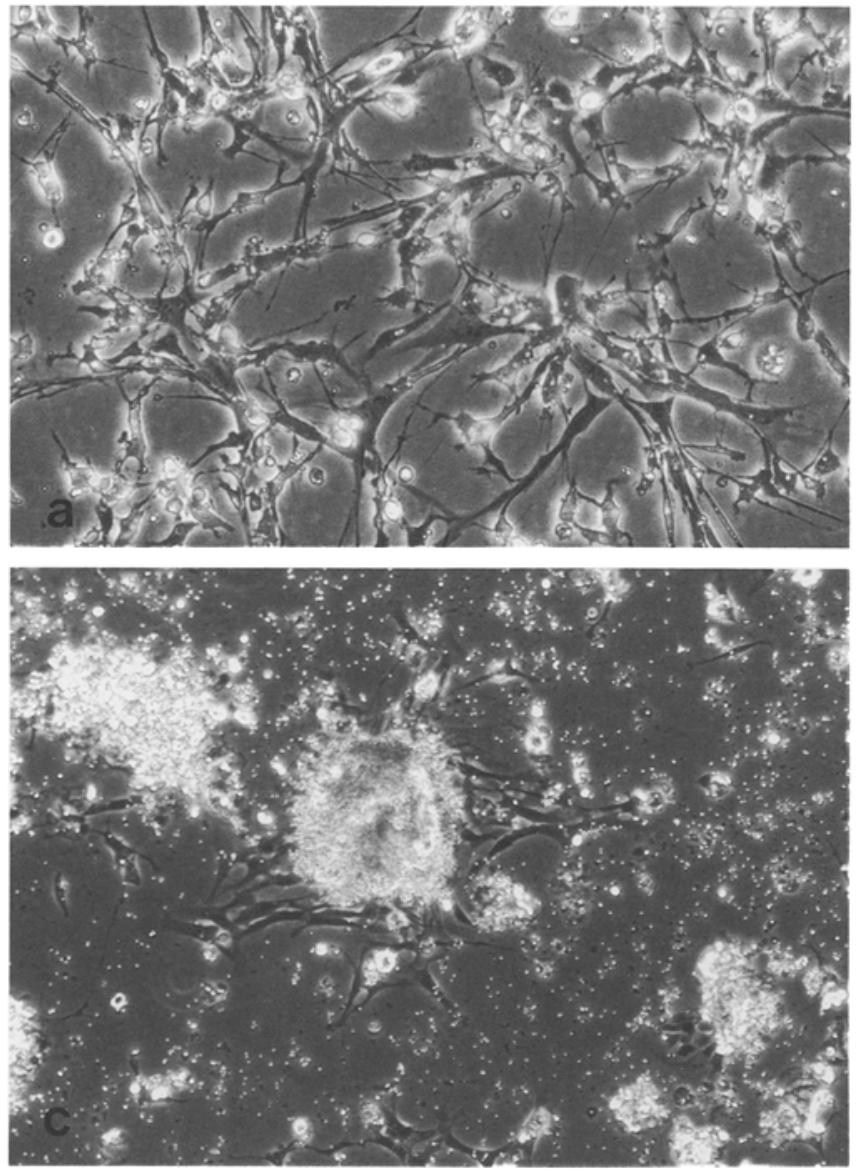

Fig. 4a-d. Interstitial cells cultured on plastic. Phase-contrast microscopy. a, b Stage-VIII a testis, 9 days in culture, $\times 95$; a singlecell population; $\mathbf{b}$ cell-cluster population. $\mathbf{c}-\mathbf{d}$ Interstitial-cell cluster after (c) 5 days and (d) 11 days in culture. $\times 60$

increased between day 5 and 8 , and then decreased. In another experiment (stage V) the incorporation of ${ }^{3} \mathrm{H}$ thymidine by the cells seeded in clusters amounted after 10 days to twice that after 7.5 days. At these two times, gonadotropin $(0,20,100,200 \mathrm{ng} / \mathrm{ml})$ had no effect on the DNA synthesis.

\section{In-vitro steroidogenic activity}

$3 \beta-H y d r o x y s t e r o i d$ dehydrogenase activity. After cell separation, the $3 \beta$-HSD activity of the single cells was variable as evidenced by differences in staining intensity. In the clusters, $3 \beta$-HSD-positive cells were mixed with $3 \beta$-HSD-negative elements; the nucleus of the latter was elongate (Fig. 6a, b). At the time of seeding, the mean individual $3 \beta$-HSD activity of the positive cells was similar in the single-cell population and in the cell-cluster population, prepared from stage-III (1), -V (2) and -VII to VIIIa (2) testes. Later, intensely and moderately stained cells, as well as negatively stained elements were present in the single-cell population (Fig. 6c). However, the number of positive cells decreased progressively after
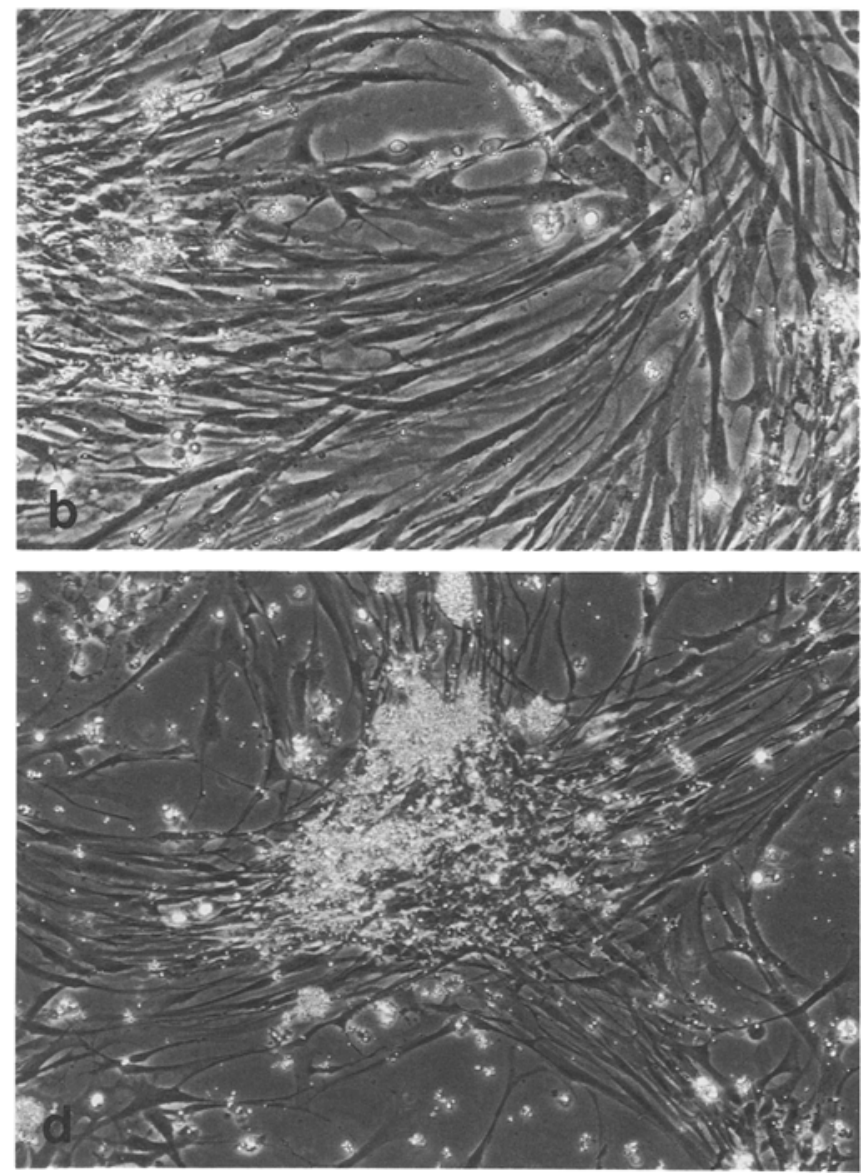

5 days, with very few remaining after $12-15$ days. In the cell-cluster population, all the cells that had separated from the clusters were intensely or moderately positive (Fig. $6 \mathrm{~d}$ ). Their $3 \beta$-HSD activity was at its highest level after culture for 5-7.5 days; it then decreased slowly, and after $12-15$ days a variable proportion of the spread cells had become negative.

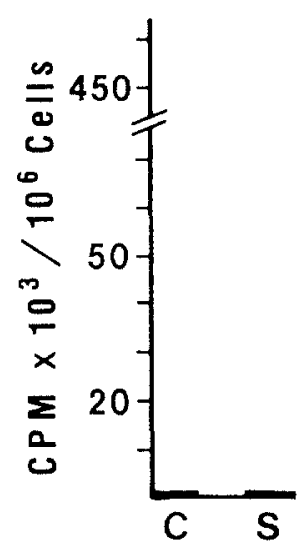

days:
2.5

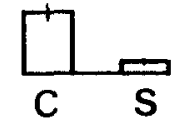

5
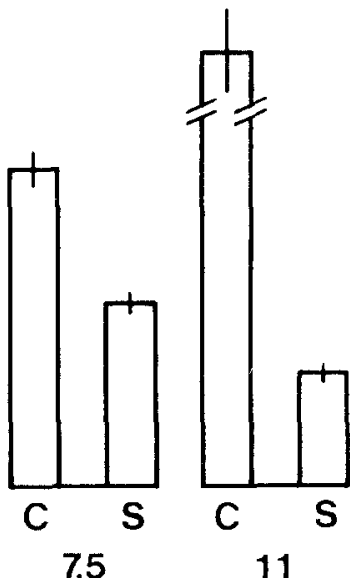

Fig. 5. Incorporation of ${ }^{3} \mathrm{H}$-thymidine by single interstitial cells $(S)$ and by cells seeded in clusters $(C)$ and cultured for $2.5-11$ days in the presence of $6 \mathrm{ng} \mathrm{GtH} / \mathrm{ml}$. Stage-VIII a testis. Mean of three wells \pm standard error 

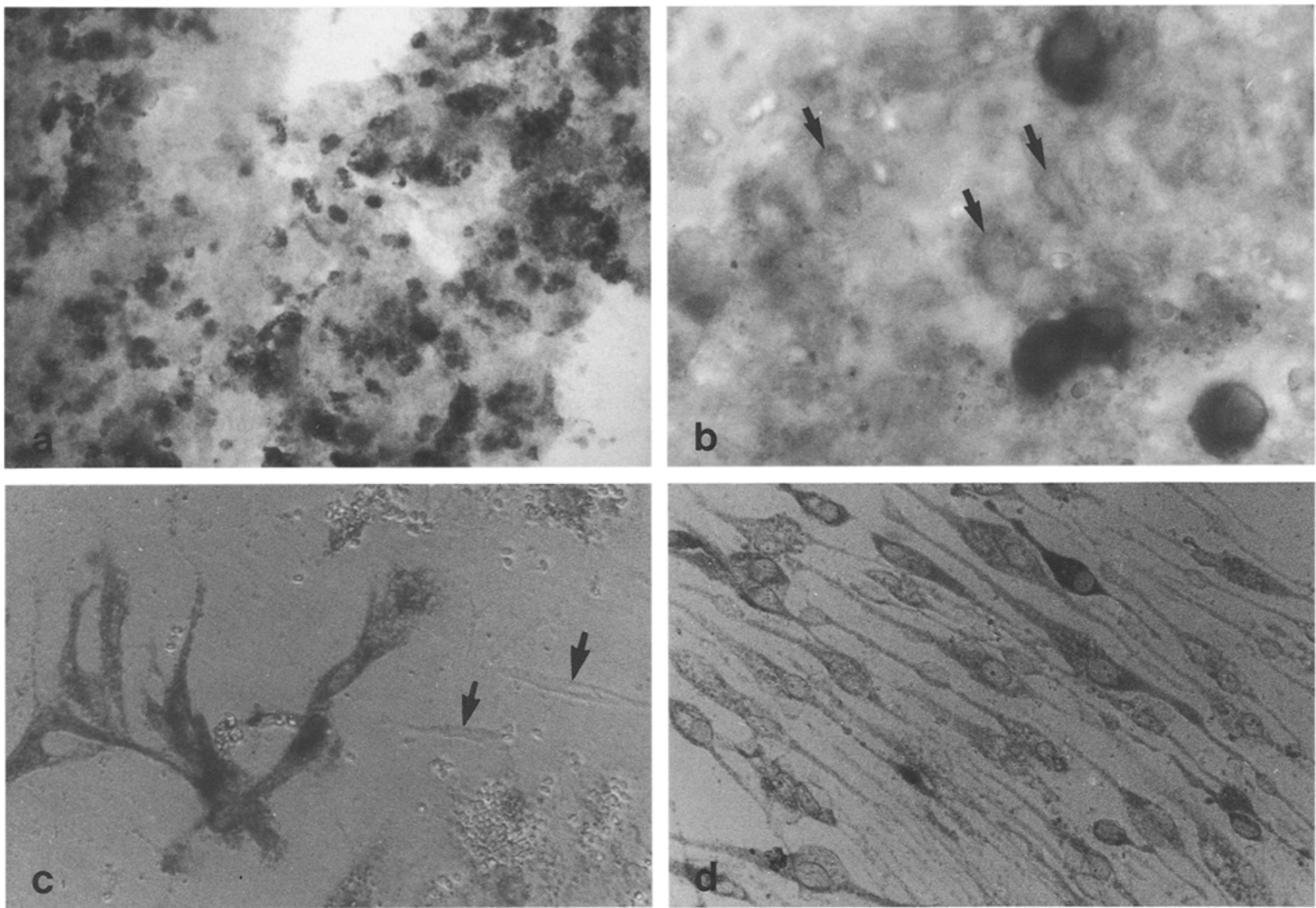

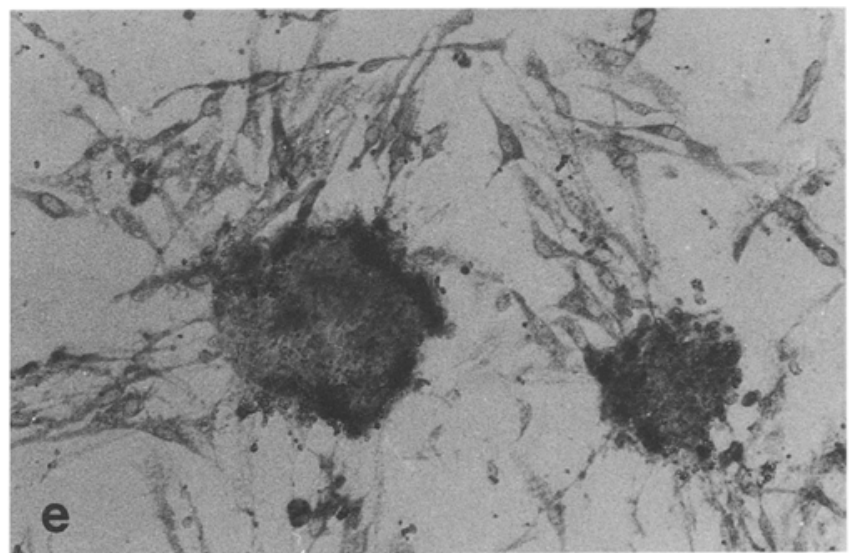

Fig. 6a-f. Light micrographs, $3 \beta$-hydroxysteroid dehydrogenase reaction of interstitial cells. a, $\mathbf{b}$, Cell clusters at the time of seeding. Stage-VIII a testis. $3 \beta$-HSD-positive cells are mixed with $3 \beta$-HSDnegative elements that show an elongated nucleus (arrows). $\mathbf{a} \times 50$; b $\times 720$. c Single-cell population after 2.5 days in culture. Stage-VII to VIIIa testis. Arrows $3 \beta$-HSD-negative fibroblast-like cells (myoid cells?) $\times 380$. d Cells spreading on plastic around a cell

Although $3 \beta$-HSD-positive cells were still visible within the cell clusters after 2.5 days, they became progressively located at the periphery (Fig. 6e); thus after the day 7 to $8,3 \beta$-HSD-positive cells were virtually absent within the clusters (Fig. $6 \mathrm{f}$ ).

Secretion of steroids. The basal and GtH-stimulated secretion of $11 \mathrm{KT}$, testosterone and androstenedione by

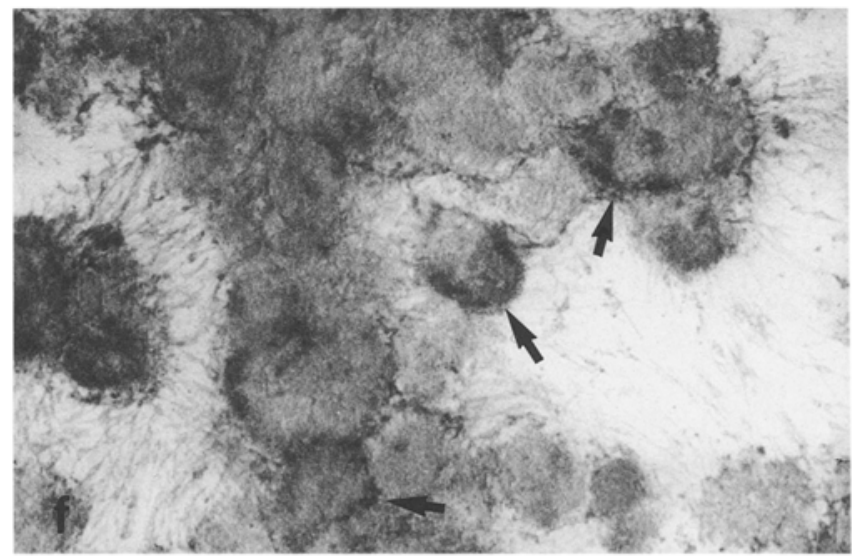

cluster, after 10 days in culture. Stage-VII to VIII a testis. $\times 420$. e Two cell clusters after 5 days in culture. Stage-VII to VIII a testis. $3 \beta$-HSD-positive cells mostly present at the periphery of the cluster. All scattered cells are more or less $3 \beta$-HSD-positive. $\times 200$. $\mathbf{f}$ Several cell clusters after 7.5 days in culture. Stage-VIII a testis. $3 \beta$-HSDpositive cells are extremely rare in the clusters and occur mainly at their periphery (arrows). $\times 25$

interstitial cells decreased rapidly throughout the culture period (1 stage-III, 3 stage-V, and 3 stage-VII to VIII a testes) (Fig. 7). After 2.5 days in culture, GtH $(100 \mathrm{ng} /$ $\mathrm{ml}$ ) stimulated the secretion of $11 \mathrm{KT}$ more effectively in cells seeded in clusters than in single cells. Stimulation by $\mathrm{GtH}$ was $7.9-16$ times greater for the former versus 1.5-4.7 times for the latter. The secretion of testosterone stimulated either by $\mathrm{GtH}$ or by $22-\mathrm{OH}$-cholesterol 


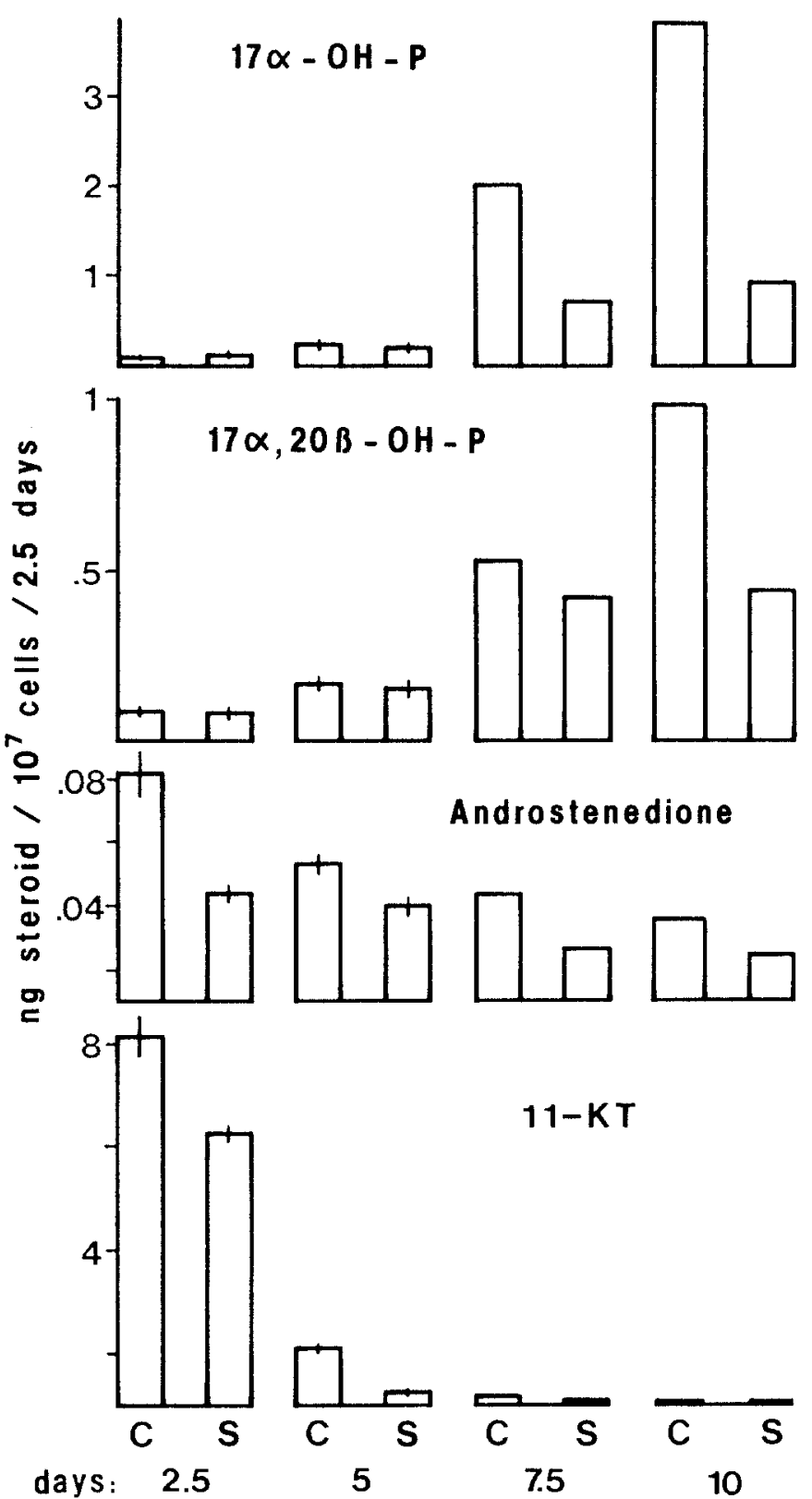

Fig. 7. Changes in GtH-stimulated $(100 \mathrm{ng} / \mathrm{ml})$ secretion of four steroids by the single-cell $(S)$ and cell-cluster $(C)$ populations prepared from one stage-VIII a testis and cultured for 10 days. Means of 3 wells \pm SE or pools of 3 wells (no SE; the coefficient of variation was routinely lower than $12 \%$ )

$(100 \mu \mathrm{M})$, decreased more rapidly in single-cell populations than in cell-cluster populations. GtH-stimulated androstenedione secretion (one stage-VIII a testis) by $10^{6}$ clustered cells was twice that of single cells (Fig. 7).

Secretion of $17 \alpha-\mathrm{OH}-\mathrm{P}$ and $17 \alpha, 20 \beta-\mathrm{OH}-\mathrm{P}$ by $10^{6}$ GtH-stimulated clustered cells, at stages V and VIIVIII a, after 2.5 days, was either identical or 1.6-2 times higher than for single cells. In most cases the secretion of these two progestagens increased during the first 7 8 days in culture, and then either slowly decreased or increased further (Fig. 7). The progestagen secretion increased more rapidly in cell-cluster populations than in single-cell populations.

\section{Ultrastructural changes throughout culture}

Interstitial cells seeded as clusters. The ultrastructure of these cells, prepared from stage-V (2), stage-VIIIa (3) and stage-VIII b-IX testes (3), and cultured either in suspension or spread onto fibronectin-coated plastic, was similar between days 2 and 12 . In both cases, intercellular junctions similar to those present in situ were observed up to 12 days of culture.

After 4 days in culture, the nuclei of Leydig cells contained less heterochromatin. The cytoplasmic organization of most of these cells was only slightly changed. The parallel SER tubules often predominated over the entwined SER tubules. The mitochondrial diameter was increased $(0.5$ to $1.9 \mu \mathrm{m})$ and their matrix was electrondense in most of the Leydig cells. The cristae were either tubulovesicular or tubular. While some myoid cells/ fibroblasts were unchanged, others with a clearer cytoplasm displayed (1) a moderate increase in the amount of the various cytoplasmic organelles; (2) an increase in the mitochondrial diameter $(0.4-1.2 \mu \mathrm{m}$ vs 0.2 $0.3 \mu \mathrm{m})$; (3) a clear mitochondrial matrix and tubular cristae. Either all the mitochondria were identical within one cell or two different types were simultaneously present (Fig. 8a). Whether the clusters were cultured either in suspension or on plastic, a differential localization of the cells was apparent: the Leydig cells were preferentially located on the outside of the clusters, while the myoid cells occurred in the center.

After 6 days, the ultrastructure of Leydig cells differed from that observed 2 days earlier by an increase in the amount of free ribosomes and RER. Leydig cells were exclusively observed at the periphery of the clusters (cultures in suspension and cultures on plastic).

After 8 days, heterochromatin in the nuclei of Leydig cells was restricted to a thin peripheral layer (Fig. 8d). An active-appearing nucleolus was present. Cells displaying typical ultrastructural features of steroidogenic elements and containing a SER formed by interrupted

Fig. 8a-e. Interstitial cells (cell-cluster population) in culture. a Fibroblast after $\mathbf{4}$ days. Stage-VIII a testis. In addition to pinocytotic vesicles (arrowheads), note filaments (small arrow) and typical large mitochondria with a clear matrix and tubular cristae. $\times 19600$. b, c Leydig cells on the surface of a cell cluster cultured in suspension for 8 days. Stage-VIII a testis. Depending on the cells, mitochondria display a clear matrix and tubular cristae or are identical to those observed in situ. b $\times 12300 ; \mathbf{c} \times 16300$. d Periphery of a cell cluster cultured in suspension for 8 days. Stage-VIIIa testis. $L$ poorly differentiated Leydig cell; $F$ typical fibroblast containing moderate-sized mitochondria with a clear matrix and tubular cristae; $M$ giant mitochondria (observed usually in slightly modified fibroblasts); $I$ "intermediate" cells; arrowheads pinocytotic vesicles; small arrows filaments; $m$ regular mitochondria; $S$ smooth endoplasmic reticulum. $\times 11200$. e Two "intermediate" cells (located near a cell cluster), cultured for 8 days on plastic. Stage-V testis. One cell $(I 1)$ is richer in pinocytotic vesicles (arrowheads), filaments (small arrows) and RER than the other (I2), which differs from a Leydig cell by the presence of some filaments and pinocytotic vesicles. In both cells, mitochondria $(m)$ possess a clear matrix and tubulovesicular cristae. $\times 18400$ 

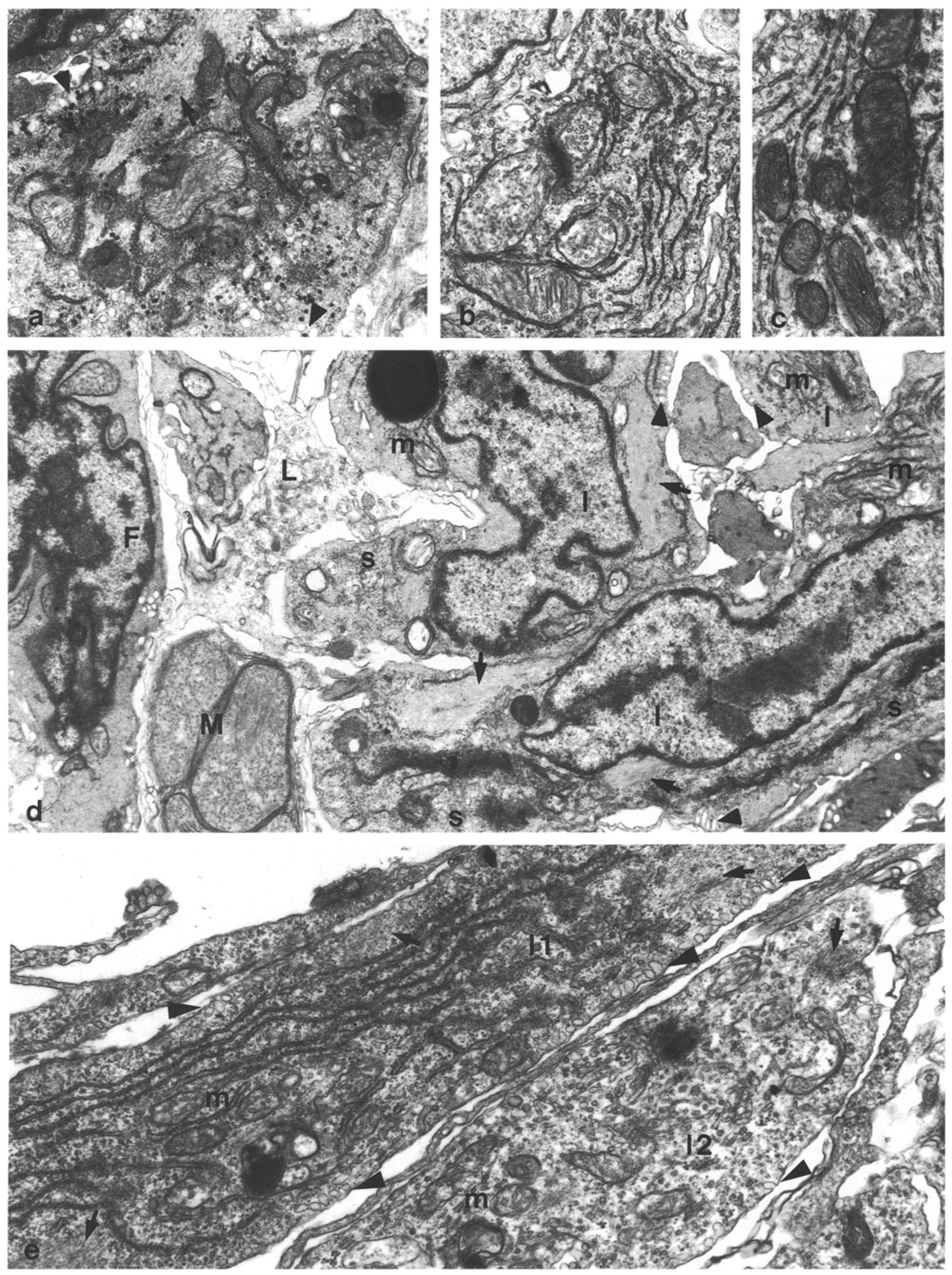
parallel tubules (Fig. 8b, c) were more numerous. Free ribosomes were sometimes abundant, and RER occurred in variable amounts. The mitochondrial matrix was either dense or electron-translucent and the cristae belonged either to the tubulovesicular or tubular type (Fig. 8b, c). Other Leydig cells had a disorganized cytoplasm, containing small vacuoles and mitochondria with a clear matrix and few tubular cristae. In the center of the clusters, typical fibroblasts were still present (Fig. 8d). Usually they possessed mitochondria with a clear matrix and tubular cristae. Others (Fig. 8d) displayed less heterochromatin, a clearer cytoplasm with less conspicuous tonofilaments, slightly more abundant cytoplasmic organelles, especially SER and RER, and larger, sometimes even giant mitochondria (diameter $\leq$ $1.6 \mu \mathrm{m}$, length $\leq 4 \mu \mathrm{m}$ ) with a clear matrix and tubulovesicular or tubular cristae. A third type of cell ("intermediate" type; Fig. 8e), mostly observed at the periphery of the clusters and distributed around them, simultaneously possessed features characteristic of (1) fibroblasts: tonofilaments, pinocytotic vesicles, and (2) Leydig cells: reduced amount of heterochromatin, well-developed SER, large mitochondria (diameter: $0.5-0.8 \mu \mathrm{m}$ ) with a clear matrix and tubulovesicular or tubular cristae. The relative abundance of these two categories of features varied among different cells, which, in addition, contained variable amounts of RER and free ribosomes.

After 10 and 12 days in culture, a gradual disappearance of typically differentiated Leydig cells was apparent. The cytoplasm of the persisting Leydig cells was less organized, endowed with small vacuoles and free ribosomes. SER was present in variable amounts, and the mitochondrial matrix was clear. Some typical fibroblasts were still visible, but the predominant cells were of the "intermediate" type.

Single interstitial cells. Changes in single interstitial cells cultured on plastic were studied only at stage VIII a (one testis). The evolution of Leydig cells and myoid cells/ fibroblasts was roughly similar to that described for these cells in clusters. However, the changes in Leydig cells were more rapid in the single-cell population, and after 8-10 days in culture they resembled those seeded in clusters 12 days earlier.

\section{Discussion}

At the time of seeding in culture, the interstitial cells present in the single-cell and cell-cluster populations have identical morphology, ultrastructure, $3 \beta$-HSD activity and buoyant density (Loir 1988). Later, there is a general trend for the single interstitial cells to show a lower steroidogenic activity than the cells seeded as clusters, and to have a time-limited ability to proliferate. These differences may be due to the other cell types (macrophages, spermatogonia, germ cells) either present or absent in the two populations. However, we assume that such differences mainly depend on the loss of the intercellular contacts between interstitial cells. Indeed, Verhoeven et al. (1986) have demonstrated that steroido- genic activity of reaggregated interstitial cells exceeds that of cells maintained in monolayers.

The secretion of androgens always decreased rapidly after seeding in culture; the mechanisms involved in this change have been discussed elsewhere (Le Gac and Loir 1988; Loir 1990a). The increase in progestagen secretion during culture, observed in both testes in spermatogenesis and in spermiation, may arise from two major events: (1) During the first few days, regressive changes caused by unknown mechanisms and responsible for the shift toward the production of $\mathrm{C}_{21}$ rather than $\mathrm{C}_{19}$ steroids may take place in the original Leydig cells. (2) After the first 5 days the rapid increase in progestagen secretion, especially in cell-cluster populations, may be mainly a consequence of the increase in the number of $3 \beta$ HSD-positive cells.

While mitoses could be observed in cultures of single cells, which incorporate ${ }^{3} \mathrm{H}$-thymidine at a low rate, in cultures of cells seeded as clusters, which actively incorporate this precursor, mitosis was never seen among cells scattered around the clusters. The volume of the clusters did not seem to decrease even though many cells had separated from them. Furthermore, after 7-8 days the clusters contained mostly fibroblast-like cells and only very few $3 \beta$-HSD-positive cells. We therefore propose the following hypothesis: After a few days in culture, the myoid cells/fibroblasts acquire the ability to proliferate, especially when they are gathered in clusters; then the resulting cells leave the clusters. At the same time, these cells acquire a steroidogenic activity; for at least two weeks they secrete only progestagens. We do not know whether they become able to synthesize androgens after this period.

It is unknown whether the fibroblasts that first proliferate and then differentiate in culture are the perilobular myoid cells or some fibroblasts originally located in the central regions of the interstitium, i.e. equivalents to the mammalian precursor mesenchymal cells. In vitro as well as in vivo, fibroblasts have the ability to divide and differentiate (Bell et al. 1979). However, in vitro this phenomenon could represent a response either to artificial substrates or to environmental changes that may mimick the factors controlling in vivo the metabolism of fibroblasts. Under the present experimental conditions, androgens disappear rapidly from the culture medium; thus, this may be the stimulus inducing the latent fibroblasts to divide and then to differentiate to steroidogenic cells. In the rat, multiplication followed by differentiation of precursor cells to Leydig cells is stimulated by destruction of the existent Leydig cells with ethylene dimethane sulphonate (EDS; Molenaar et al. 1986), which blocks the production of androgens (Verhoeven et al. 1989).

Striking changes in the morphological appearance of Leydig cells and fibroblasts were observed at different phases of the reproductive cycle, either in situ or after cell separation. At the onset and during full spermiation, most of the Leydig cells were structurally well differentiated. It is during this period that the plasma levels of sex steroids, and especially androgens, are at their highest values throughout the reproductive cycle of the 
trout (Scott and Sumpter 1989). Such a relationship between ultrastructure of Leydig cells and steroidogenic activity has already been reported in a gonochoristic teleost (Loir et al. 1989), a protogynous fish (Yeung et al. 1985), and particularly well-documented for an amphibian (Pudney et al. 1983). On the other hand, it has been shown in mammals that the proportion of SER in the cytoplasm of Leydig cells reflects testosterone secretion (Ewing and Zirkin 1985).

The changes affecting cytoplasmic organization and the mitochondrial structure in Leydig cells as observed in regressing and regressed testes suggest some degree of degeneration. These cellular alterations are accompanied by a decrease in plasma sex steroids to low levels (Scott and Sumpter 1989). Similar signs of degeneration correlated with a decreased androgen secretion have also been observed in two teleost species (Yeung et al. 1985; Loir et al. 1989) and in some mammals during testicular regression (for review, see Tähkä 1988).

Thus, in trout, as already proposed for Myleus ternet$z i$ (Loir et al. 1989), Leydig cells are likely to undergo a morphological/functional cycle in relation to spermatogenesis. However, it is unknown at present whether Leydig cells (i) recover the ability to synthesize steroids and undergo cyclic seasonal changes, or (ii) die at the end of a cycle to be replaced by new ones at the onset of the next cycle. In testes resuming or involved in spermatogenesis, most of the cells located in the interstitium cannot be identified as either Leydig cells or fibroblasts. These "intermediate" cells may correspond to a dedifferentiated stage of Leydig cells. At least in man such a dedifferentiation has been reported after estrogen treatment (Schulze 1988). On the other hand, the "intermediate" cells could reflect the progressive differentiation of fibroblast-like precursor cells to new proper Leydig cells. Assuming that some similarity may exist between the in-vivo and in-vitro behavior of the interstitial cells, our in-vitro observations are in favor of the last interpretation. Thus, for the trout, we propose the following hypothesis: At the end of a reproductive cycle Leydig cells degenerate, while plasma androgen levels decrease and remain low during the beginning of the next cycle. At this time a population of fibroblastic precursor cells is stimulated to divide and to differentiate progressively to Leydig cells. During spermatogenesis, these cells might be poorly differentiated; however, at the end of spermatogenesis, they are transformed to fully differentiated elements, active in androgen production. Oota and Yamamoto (1966) have given a detailed description of the immature Leydig cells in juvenile trout. These cells resemble (i) some of the elements observed in our in-situ material at the onset of spermatogenesis and (ii), the "intermediate" cells occurring after 8 days in culture. Notably, they have large (up to $5 \mu \mathrm{m}$ ) mitochondria with a clear matrix and tubular cristae. Nicholls and Graham (1972) suggested that, in Cichlasoma nigrofasciatum, Leydig cells may arise from interstitial fibroblast-like cells. According to Yeung et al. (1985), the situation might be the same in Monopterus albus at the time of sex reversal. In mammals, there is general agreement (Hardy et al. 1989) that the postnatal genera- tion of Leydig cells arises principally via differentiation from precursor mesenchymal cells (fibroblast-like cells with a well-developed SER).

Acknowledgements. This work was supported in part by a grant from the Institut National de la Recherche Agronomique (AIP 4433). We thank Dr. B. Breton for the kind gift of s-GtH and Dr. B. Jegou for critical reading of the manuscript. We are grateful to Mrs. C. Cauty for her skillful assistance in preparing sections for electron microscopy, to J.Y. Lefeuvre for excellent assistance in preparing the figures, and to J. Hall and Dr. D. Webb for help with the English text. Electron microscopy was carried out at the Centre Commun de Microscopie Electronique à Transmission de l'Université de Rennes.

\section{References}

Bell E, Marek L, Sher S, Merrill C, Levinstone D, Young I (1979) Do diploid fibroblasts in culture age? Int Rev Cytol [Suppl] $10: 1-9$

Billard R, Escaffre AM (1975) Identification des stades de la spermatogenése de la truite fario d'après la morphologie des gonades et la spermiation. Bull Fr Pisci 256:111-118

Breton B, Prunet P, Reinaud P (1978) Sexual differences in salmon gonadotropin. Ann Biol Anim Biochim Biophys 18:759-765

Ewing LL, Zirkin B (1985) Leydig cell structure and steroidogenic function. Recent Prog Horm Res 39:599-619

Fostier A, Jalabert B (1986) Steroidogenesis in rainbow trout (Salmo gairdneri) at various preovulatory stages: changes in plasma hormone levels and in vivo and in vitro responses of the ovary to salmon gonadotropin. Fish Physiol Biochem 2:87-99

Gabbiani G, Montandon D (1977) Reparative processes in mammalian wound healing: the role of contractile phenomena. Int Rev Cytol 48:187-219

Grier HJ (1981) Cellular organization of the testis and spermatogenesis in fishes. Am Zool 21:345-357

Hardy MP, Zirkin BR, Ewing LL (1989) Kinetic studies on the development of the adult population of Leydig cells in testes of the pubertal rat. Endocrinology 124:762-770

Le Gac F, Loir M (1988) Control of testis function in fish: in vitro studies of gonadotropic regulation in the trout (Salmo gairdneri). Reprod Nutr Dev 28:1031-1046

Levy H, Deane HW, Rubin BL (1959) Visualisation of steroid-3-ol dehydrogenase activity in tissues of intact and hypophysectomised rats. Endocrinology 65:933-943

Loir M (1988) Trout Sertoli and Leydig cells: isolation, separation and culture. Gamete Res 20:437-458

Loir M (1989) Trout Sertoli cells and germ cells in primary culture: I. Morphology and ultrastructural study. Gamete Res 24:151169

Loir M (1990a) Trout steroidogenic testicular cells in primary culture. 1: Changes in free and conjugated androgen and progestagen secretions. Effects of gonadotropin, serum and lipoproteins. Gen Comp Endocrinol (in press)

Loir M (1990b) Trout steroidogenic testicular cells in primary culture. 2: Steroidogenic activity of interstitial cells, Sertoli cells and spermatozoa. Gen Comp Endocrinol (in press)

Loir M, Margeridon A, Cauty C (1989) Leydig cells in Myleus ternetzi testes. Aquat Living Resour 2:57-61

Molenaar R, de Rooij D, Rommerts FFG, van der Molen H (1986) Repopulation of Leydig cells in mature rats after selective destruction of the existent Leydig cells with ethylene dimethane sulfonate is dependent on luteinizing hormone and not folliclestimulating hormone. Endocrinology 118:2546-2554

Nagahama Y (1986) Testis. In: Pang PKT, Schreibman MP (eds) Vertebrate endocrinology: fundamentals and biomedical implications. Academic Press, New York, pp 399-437

Nicholls TJ, Graham GP (1972) The ultrastructure of lobule boundary cells and Leydig cell homologs in the testis of a cichlid 
fish, Cichlasoma nigrofasciatum. Gen Comp Endocrinol 19:133-146

Oota I, Yamamoto K (1966) Interstitial cells in the immature testes of the rainbow trout. Ann Zool Jpn 39:142-148

Pudney J, Canick JA, Mak P, Callard GV (1983) The differentiation of Leydig cells, steroidogenesis, and the spermatogenetic wave in the testis of Necturus maculosus. Gen Comp Endocrinol $50: 43-66$

Sakai N, Ueda H, Suzuki N, Nagahama Y (1989) Involvement of sperm in the production of $17 \alpha, 20 \beta$-dihydroxy-4-pregnen-3one in the testis of spermiating rainbow trout Salmo gairdneri. Biomed Res 10:131-138

Schulze C (1988) Response of the human testis to long-term estrogen treatment: morphology of Sertoli cells, Leydig cells and spermatogonial stem cells. Cell Tissue Res $251: 31-43$

Scott AP, Sumpter JP (1989) Seasonal variations in testicular germ cell stages and in plasma concentration of sex steroids in male rainbow trout (Salmo gairdneri) maturing at 2 years old. Gen Comp Endocrinol 73:46-58

Tähkä KM (1988) Effect of differential photoperiod treatment on Leydig cell ultrastructure in the bank vole (Clethrionomys glareolus, S) Gen Comp Endocrinol 71:318-330

Verhoeven G, Cailleau J, van der Schueren B, Cassiman JJ (1986) The dynamics of steroid and adenosine $3^{\prime}, 5^{\prime}$-cyclic monophosphate output in perifused interstitial cell aggregates derived from prepubertal rat testes. Endocrinology 119:1476-1488

Verhoeven G, Cailleau J, Morris ID (1989) Inhibitory effects of alkane sulphonates on the function of immature rat Leydig, Sertoli and peritubular cells cultured in vitro. J Mol Endocrinol 2:145-155

Yeung WSB, Adal MN, Hui SWB, Chan STH (1985) The ultram structural and biosynthetic characteristics of steroidogenic cells in the gonad of Monopterus albus (Teleostei) during natural sex reversal. Cell Tissue Res 239:383-394 